Vol. 4: 11-17.

\title{
Evaluation of conditions for fermentation of fish offal
}

\author{
T. Mikael Lassén \\ Division of Animal Nutrition, Department of Animal Science and Animal Health, Royal Veterinary \\ and Agricultural University, Bülowsvej 13, DK-1870 Frederiksberg C., Denmark
}

\begin{abstract}
Conditions for the lactic acid fermentation of fish offal were evaluated regarding the effect of substrate concentration $(2,5$ and $10 \%$ dextrose), preacidification with lactic acid (initial pH of 6.8 , to 6.5 or 6.0), and inoculum size of Lactobacillus plantarum $\left(10^{7}, 10^{8}\right.$ and $10^{9}$ colony forming units $\left.(\mathrm{cfu}) / \mathrm{g}\right)$. $\mathrm{pH}$ and lactic acid production were monitored during a two-week storage period. A small-scale silo for fermenting fish offal was also constructed, and measurement of redox potential was evaluated as a means to estimate bacterial growth conditions. The most favourable conditions for fermentation, manifested by a low and stable $\mathrm{pH}$ and high lactic acid production, were achieved with an inoculum size of $10^{8} \mathrm{cfu} / \mathrm{g}$ and $5 \%$ dextrose. Preacidification did not affect final $\mathrm{pH}$. Redox potential was shown to give a reliable estimate of growth conditions for bacteria under anaerobic conditions by rapidly falling to below $-550 \mathrm{mV}$ in silage with a high lactic acid concentration.
\end{abstract}

Key words: Lactobacillus plantarum, preservation, animal by-product, silage, lactic acid, redox potential, spoilage

\section{Introduction}

Lactic acid fermentation may be a useful alternative to deep freezing, chemical acidification and protein concentrate as storage method for animal by-products, provided a product of good hygienic quality can be obtained.

To achieve proper fermentation, the material must contain lactic acid bacteria and nutrients necessary for optimal fermentation, and have a temperature within the range of the fermentative bacteria. The nutritional demands of the lac- tic acid bacteria include fermentable carbohydrates, amino acids, nucleotides and vitamins (Beck 1978).

The preserving properties of lactic acid bacteria (LAB) are mainly due to production of organic acids (Hurst 1973, Hurst and CollinsThomsson 1979, Speck 1981), the undissociated molecules of which are responsible for the antimicrobial activity, with decreasing $\mathrm{pH}$ of the product, the proportion of undissociated molecules of organic acid increases (Ingram et al. 1959, Baird-Parker 1980). Further, substances with specific activity against gram-positive bac- 
Lassén, T. M.: Evaluation of conditions for fermentation of fish offal

teria have been observed in herring silage (Lindgren and Clevström 1978).

Lactic acid fermentation of animal by-products can be achieved by adding LAB and fermentable carbohydrates to minced animal byproducts. The fermented products are usually stored at temperatures ranging from $20^{\circ} \mathrm{C}$ to $30^{\circ} \mathrm{C}$ (Nilsson and Rydin 1965, Mackie et al. 1971, Stanton and Yeoh 1977, Raa 1980, Lindgren and Pleje 1983).

The present investigation was part of a project studying the biopreservation of animal by-products with lactic acid bacteria. This part of the study investigated the optimum level of carbohydrate addition, initial $\mathrm{pH}$ and inoculum size for the fermentation process. In addition, a method for measuring redox potential was developed and evaluated as a means for estimating growth conditions for bacteria.

\section{Material and methods}

Fish offal (viscera and heads) from herring (Clupea harengus) caught in the North Sea in autumn was obtained from Gilleleje Processing Plant, Gilleleje, Denmark. The offal was minced coarsely through a 10 -mm plate, and deep-frozen within $6 \mathrm{~h}$. The offal was kept at $-20^{\circ} \mathrm{C}$ until $12 \mathrm{~h}$ before it was to be used for fermentation.

In experiment 1, batches of herring offal, each weighing $150 \mathrm{~g}$, were prepared for fermentation according to a $3 \times 3 \times 3$ factorial design regarding level of fermentable carbohydrate (2, 5 and $10 \%)(\mathrm{v} / \mathrm{w})$ dextrose), inoculum size (107, $10^{8}$, and $10^{9}$ colony forming units (cfu)/g, Lactobacillus plantarum, (L.p), Chr. Hansen's Lab. A/ $\mathrm{S}$ Hørsholm, Denmark), and initial pH (original $\mathrm{pH}$ of 6.8 in the offal lowered to 6.5 and 6.0, respectively, with $90 \%$ (v/v) L-lactic acid, Merck Nr. 366). All combinations of substrate, inoculum size and initial $\mathrm{pH}$ were prepared in triplicate and treated in a waterbath at $25^{\circ} \mathrm{C}$. pH and lactic acid were measured after one, two, three, seven and fourteen days.
Lactic acid production in the fermented material was measured by titrating $5 \mathrm{~g}$ of silage suspended in $25 \mathrm{ml}$ of distilled water to $\mathrm{pH} 7$ with $0.1 \mathrm{M} \mathrm{NaOH}$. pH was measured using a Radiometer $\mathrm{PH} 28 \mathrm{pH}$ meter equipped with a GK24018 probe whereafter the sample was titrated with a TTT11 titrator (Radiometer A/S, Rødovre, Denmark). The lactic acid content (\%) was determined by multiplying the volume $(\mathrm{L})$ of the $\mathrm{NaOH}$ by the molarity (M) of the $\mathrm{NaOH}$ and the molecular weight of lactic acid (90.06) and dividing it by the sample weight (Formula 1) The \% lactic acid was determined by subtracting the \% LA (w/w) before fermentation from the \% LA of the fermented sample.

$$
\% \mathrm{LA}=\frac{(\mathrm{L} \mathrm{NaOH} \times \mathrm{M} \mathrm{NaOH} \times 90.06)}{5 \mathrm{~g} \text { (sample weight })} \times 100
$$

In experiment 2 herring offal was fermented with $10^{7} \mathrm{cfu} / \mathrm{g} \mathrm{L}$.p, 0,2 and $5 \%$ dextrose at $25^{\circ} \mathrm{C}$ in order to produce a poor quality silage for use in the biochemical studies (Lassén 1995b). Measurement of redox potential was tested and evaluated as a tool for estimating bacterial growth conditions in the product. All silos were prepared in triplicate and subjected to all measurements.

Redox potential (E) was measured directly on the material with a platinum electrode (P1101) and a saturated calomel reference electrode (K401) using a pH meter (PH28). E at pH 7 was calculated from formula 2

$$
E_{(p H 7.0)}=E_{0}+58.1+244.1 X(p H-7)
$$

where $\mathrm{E}_{0}$ is the actual reading, 244.1 is the potential of the calomel electrode at the temperature at which the reading takes place, 58.1 is a constant, and $\mathrm{pH}$ is the measured $\mathrm{pH}$ of the sample (Huss and Larsen 1979).

Statistical analyses for experiment 1 were performed according to the GLM-procedure in SAS (SAS 1985). Changes in pH development and lactic acid production were evaluated according to the following split plot design model: 


\section{AGRICULTURAL SCIENCE IN FINLAND}

Vol. 4: 11-17.

$\mathrm{Y}_{i j k m}=\mathrm{m}+\mathrm{a}_{\mathrm{i}}+\mathrm{b}_{\mathrm{j}}+\mathrm{c}_{\mathrm{k}}+\mathrm{d}(i j k)+\mathrm{e}_{1}+(\mathrm{ab})_{i j}+(\mathrm{ac})_{i k}+$ $(\mathrm{ae})_{i l}+(\mathrm{bc})_{j k}+(\mathrm{be})_{j l}+(\mathrm{ce})_{k l}+(\mathrm{abc})_{i j k}+(\mathrm{abe})_{i j l}$ $+(\text { bce })_{j k l}+(\text { ace })_{i k l}+(\text { abce })_{i j k l}+\mathrm{e}_{i j k l m}$

where,

$\mathrm{Y}_{i j k \mathrm{~m}}=$ the $\mathrm{ijklm}$ th observation,

$\mu=$ general mean,

$a_{i}=$ fixed effect of dextrose level,

$b_{j}=$ fixed effect of inoculum size,

$\mathrm{c}_{k}=$ fixed effect of initial $\mathrm{pH}$,

$\mathrm{d}(i j k)=$ random silo within dextrose level, inoc-

ulum size and initial $\mathrm{pH}$,

$e_{1}=$ fixed effect of storage time,

$(a b)_{i j}=$ interaction between dextrose level and inoculum size,

$(\mathrm{ac})_{i k}=$ interaction between dextrose level and initial $\mathrm{pH}$,

$(\mathrm{ae})_{i l}=$ interaction between dextrose level and storage time,

(bc) ${ }_{j k}=$ interaction between inoculum size and initial $\mathrm{pH}$,

(be) $)_{j l}=$ interaction between inoculum size and storage time,

$(\text { ce })_{k l}=$ interaction between initial $\mathrm{pH}$ and storage time,

$(\mathrm{abc})_{i j k}=$ interaction between dextrose level, inoculum size and initial $\mathrm{pH}$,

$(\text { abe })_{i j l}=$ interaction between dextrose level, inoculum size and storage time,

$(\text { bce })_{j k l}=$ interaction between inoculum size, initial $\mathrm{pH}$ and storage time,

$(\text { ace })_{i k l}=$ interaction between dextrose level, initial $\mathrm{pH}$ and storage time,

$(\text { abce })_{i j k l}=$ interaction between dextrose level, inoculum size, initial $\mathrm{pH}$, and storage time,

$\mathrm{e}_{i j k l m}=$ random error.

Treatment effects were tested against sample effect, using sample within dextrose level, inoculum size and initial $\mathrm{pH}$ as an error term.

\section{Results}

The effect of substrate concentration, inoculum size and preacidification on $\mathrm{pH}$ and lactic acid production in the silage is shown in Table 1. Generally, the results of measurements on individual silos within treatments showed very little variation between silos, but treatment effects (dextrose level, inoculum size and initial $\mathrm{pH}$ ) were all highly significant $(\mathrm{P}<0.001)$. Lactic acid production and final $\mathrm{pH}$ decreased with increasing dextrose concentration, and an increase in inoculum level from $10^{7}$ to $10^{9} \mathrm{cfu} / \mathrm{g}$ resulted in faster lactic acid production and a decrease in $\mathrm{pH}$ during the first 24 hours. Slow initial fermentation ( $2 \%$ dextrose and $\left.10^{7} \mathrm{cfu} / \mathrm{g}\right)$ led to lower lactic acid concentrations and high final $\mathrm{pH}$. Despite a significant treatment effect, preacidification of herring offal before fermentation had little effect on lactic acid production and final $\mathrm{pH}$ within the inoculum and dextrose level (Table 1).

Results of small-scale silo fermentation (Experiment 2) showed that fermentation without added carbohydrate caused $\mathrm{pH}$ to decrease from an initial value of 6.8 to 6.4 after $24 \mathrm{~h}$, and then to increase to 6.8 in two days. The final $\mathrm{pH}$ after seven days at $25^{\circ} \mathrm{C}$ was about 6.5 , but very little lactic acid was produced in this silage. In silage produced with $10^{7} \mathrm{cfu} / \mathrm{g}$ L.p and $5 \%$ dextrose, $\mathrm{pH}$ decreased from an initial 6.8 to 4.4 in one week; over $2 \%$ lactic acid was produced during the first week of fermentation. Lactic acid fermentation with $2 \%$ dextrose as carbohydrate source produced poor quality silage. Slow initial lactic acid production and a slow initial $\mathrm{pH}$ decline resulted in a putrefied product after two weeks (Fig. 1a).

Measurement of redox potential in the fermented silage yielded identical results for within time and treatment measurements, and showed that the redox potential only decreased slightly in batches without dextrose and then increased to its initial level. With $2 \%$ dextrose addition the redox potential decreased from 0 to $-550 \mathrm{mV}$ during the first 24 hours but then increased to its initial level within seven days. The redox potential remained below $-550 \mathrm{mV}$ throughout the experimental period in the silage produced by addition of $5 \%$ dextrose (Fig. 1b). 


\section{AGRICULTURAL SCIENCE IN FINLAND}

\section{Lassén, T. M.: Evaluation of conditions for fermentation of fish offal}

Table 1. Effect of level of dextrose addition, inoculum size and preacidification on changes in $\mathrm{pH}$ and $\%$ lactic acid production (LA) in fermented herring offal. (Means of 3 measurements per treatment for which standard deviation ranges from 0 to 0.12 for $\mathrm{pH}$ and 0 to 0.12 for $\mathrm{LA}$ ). ( $\mathrm{cfu}=$ colony forming units)

\begin{tabular}{|c|c|c|c|c|c|c|c|c|c|c|c|}
\hline \multirow{3}{*}{$\begin{array}{c}\text { Dextrose } \\
\%\end{array}$} & \multirow{3}{*}{$\mathrm{Cfu} / \mathrm{g}$} & \multicolumn{10}{|c|}{ Storage time, days } \\
\hline & & \multicolumn{2}{|c|}{0} & \multicolumn{2}{|c|}{1} & \multicolumn{2}{|c|}{2} & \multicolumn{2}{|c|}{7} & \multicolumn{2}{|c|}{14} \\
\hline & & $\mathrm{pH}$ & LA & $\mathrm{pH}$ & LA & $\mathrm{pH}$ & LA & $\mathrm{pH}$ & LA & $\mathrm{pH}$ & LA \\
\hline \multirow{9}{*}{2} & & 6.8 & 0.0 & 5.2 & 0.1 & 4.8 & 1.3 & 5.3 & 0.9 & 5.6 & 0.2 \\
\hline & $10^{7}$ & 6.5 & 0.0 & 5.1 & 0.4 & 4.7 & 1.6 & 5.6 & 0.3 & 5.8 & 0.1 \\
\hline & & 6.0 & 0.0 & 5.1 & 0.4 & 4.7 & 1.6 & 5.1 & 0.2 & 5.2 & 0.2 \\
\hline & & 6.8 & 0.0 & 5.1 & 0.4 & 4.6 & 1.9 & 4.9 & 1.3 & 5.0 & 1.1 \\
\hline & $10^{8}$ & 6.5 & 0.0 & 5.0 & 0.7 & 4.7 & 1.6 & 5.3 & 0.3 & 5.2 & 0.3 \\
\hline & & 6.0 & 0.0 & 4.9 & 1.0 & 4.6 & 1.9 & 5.1 & 1.3 & 5.0 & 1.3 \\
\hline & & 6.8 & 0.0 & 4.8 & 1.3 & 4.5 & 2.2 & 4.3 & 2.8 & 4.4 & 2.5 \\
\hline & $10^{9}$ & 6.5 & 0.0 & 4.7 & 1.6 & 4.4 & 2.5 & 4.4 & 2.6 & 4.2 & 2.5 \\
\hline & & 6.0 & 0.0 & 4.6 & 1.8 & 4.4 & 2.5 & 4.2 & 3.1 & 4.3 & 2.9 \\
\hline \multirow{9}{*}{5} & & 6.8 & 0.0 & 5.0 & 0.7 & 4.7 & 1.6 & 4.4 & 2.5 & 4.7 & 1.7 \\
\hline & $10^{7}$ & 6.5 & 0.0 & 4.9 & 1.0 & 4.7 & 1.6 & 4.6 & 1.9 & 4.7 & 1.7 \\
\hline & & 6.0 & 0.0 & 4.9 & 1.0 & 4.6 & 1.9 & 4.5 & 2.2 & 4.7 & 2.0 \\
\hline & & 6.8 & 0.0 & 5.0 & 0.8 & 4.6 & 1.9 & 4.3 & 2.8 & 4.6 & 2.3 \\
\hline & $10^{8}$ & 6.5 & 0.0 & 4.9 & 1.1 & 4.5 & 2.2 & 4.3 & 2.8 & 4.5 & 2.4 \\
\hline & & 6.0 & 0.0 & 4.8 & 1.3 & 4.5 & 2.1 & 4.3 & 2.7 & 4.8 & 1.8 \\
\hline & & 6.8 & 0.0 & 4.5 & 2.2 & 4.4 & 2.5 & 4.1 & 3.4 & 4.2 & 3.0 \\
\hline & $10^{9}$ & 6.5 & 0.0 & 4.6 & 1.8 & 4.3 & 2.7 & 4.1 & 3.3 & 4.2 & 3.0 \\
\hline & & 6.0 & 0.0 & 4.5 & 2.2 & 4.3 & 2.8 & 4.0 & 3.7 & 4.2 & 3.3 \\
\hline \multirow{9}{*}{10} & & 6.8 & 0.0 & 5.1 & 0.4 & 4.7 & 1.6 & 4.4 & 2.5 & 4.2 & 3.1 \\
\hline & $10^{7}$ & 6.5 & 0.0 & 5.0 & 0.7 & 4.7 & 1.6 & 4.4 & 2.5 & 4.2 & 3.1 \\
\hline & & 6.0 & 0.0 & 4.9 & 1.0 & 4.6 & 1.9 & 4.4 & 2.5 & 4.1 & 3.4 \\
\hline & & 6.8 & 0.0 & 5.1 & 0.4 & 4.7 & 1.6 & 4.5 & 2.2 & 4.4 & 2.5 \\
\hline & $10^{8}$ & 6.5 & 0.0 & 4.9 & 1.0 & 4.6 & 1.9 & 4.4 & 2.5 & 4.3 & 2.8 \\
\hline & & 6.0 & 0.0 & 4.8 & 1.3 & 4.5 & 2.2 & 4.3 & 2.8 & 4.2 & 3.1 \\
\hline & & 6.8 & 0.0 & 4.9 & 1.0 & 4.5 & 2.2 & 4.4 & 2.5 & 4.2 & 3.0 \\
\hline & $10^{9}$ & 6.5 & 0.0 & 4.6 & 1.9 & 4.3 & 2.8 & 4.1 & 3.4 & 4.1 & 3.4 \\
\hline & & 6.0 & 0.0 & 4.6 & 2.0 & 4.3 & 2.8 & 4.1 & 3.4 & 4.1 & 3.6 \\
\hline
\end{tabular}

\section{Discussion}

The amount of carbohydrate necessary to ferment animal offal successfully with Lactobacillus plantarum was evaluated with dextrose because it is readily fermentable, and the results would not be confounded by a more complex carbohydrate or by-product source. Dextrose lev- els of $2-10 \%$ resulted in decreased $\mathrm{pH}$ after two days. However, $2 \%$ dextrose led to putrefied silage after one week, which was probably caused by competing bacteria in the silage, which could grow if the $\mathrm{pH}$ did not decrease to below 4.5 in two days. Another possibility is that only small amounts of lactic acid were produced during the initial $\mathrm{pH}$ decrease. $10 \%$ dextrose, on the other hand, led to slower initial fermentation but more 
Vol. 4: 11-17.
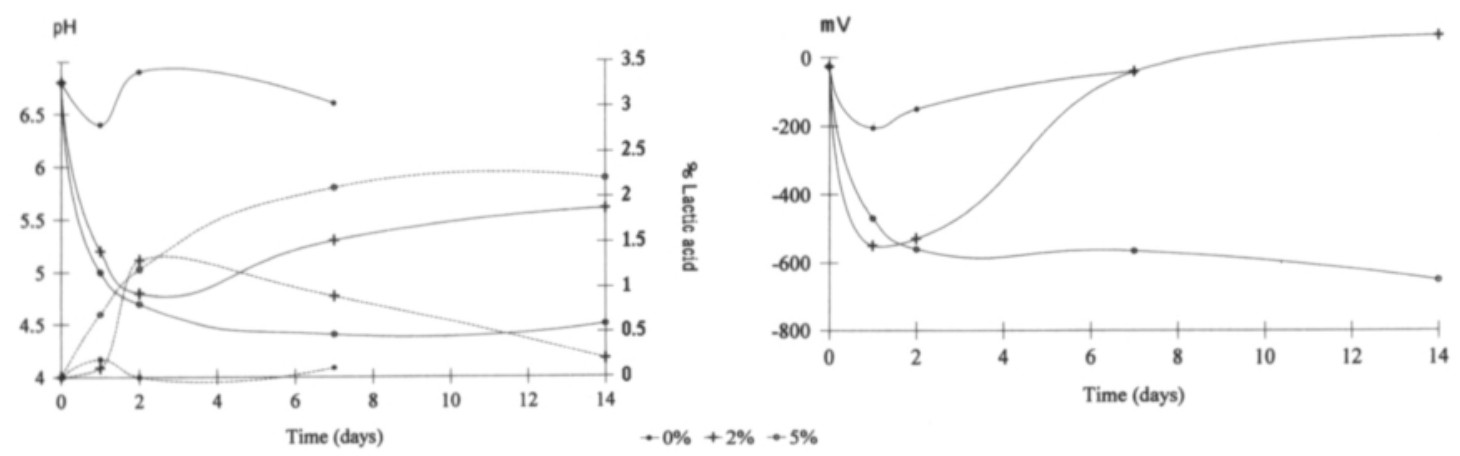

Fig. 1. Fermentation of herring offal with $10^{7}$ colony forming units/g of Lactobacillus plantarum at $25^{\circ} \mathrm{C}$. a) - changes in $\mathrm{pH} \longrightarrow \%$ LA. b) - redox potential.

stable silage during storage. The slower initial fermentation might be caused by a high osmotic pressure, which also slows initial growth of lactic acid bacteria (Nester et al. 1978). Hence, the $5 \%$ dextrose addition level was considered the most suitable for fermentation under the conditions tested. The results obtained conform with those from fermentation of poultry offal (Urlings 1992), where $4 \%$ dextrose was the substrate level giving the most successful fermentation with Lactobacillus plantarum.

The combined effects of decreased $\mathrm{pH}$ and increased concentration of undissociated lactic acid molecules inhibit growth of spoilage bacteria, which explains why more lactic acid was produced with a faster initial $\mathrm{pH}$ decrease. Slow initial lactic acid production followed by a slow $\mathrm{pH}$ decrease and the availability of substrate facilitate growth of spoilage bacteria. Certain spoilage bacteria can also use lactic acid as an energy source when no fermentable sugars are available (Pelczar et al. 1977). This may result in decreased lactic acid content and putrefaction of the silage (Raa 1980), as was observed here after one week at low dextrose concentrations (2\%). The lactic acid concentrations which inhibit growth of spoilage bacteria and result in a $\mathrm{pH}$ of under 4.4 in herring offal have been reported by Lindgren and Pleje (1983) and Hassan and Heath (1986) to be above $4.0 \%$. This finding differs from that of the present study, where the highest lactic acid concentration was $3.7 \%$, which corresponded to a $\mathrm{pH}$ of 4.0 after one week of fermentation with $10^{9} \mathrm{cfu} / \mathrm{g}$ and $5 \%$ dextrose. Lactic acid production decreased when $10 \%$ dextrose was used as a carbohydrate source, which again may be caused by initial suppression of the growth of lactic acid bacteria owing to high osmotic pressure in the raw material (Hassan and Heath 1986). The decline in the lactic acid content of samples prepared with less than $10 \%$ dextrose, and also in that of samples with a pH below 4.2, in which growth of spoilage bacteria could be considered to have ceased, may be explained by hydrolysis of fish bone, which neutralizes the silage. Consequently, more lactic acid has to be produced to retain a low $\mathrm{pH}$. This is, however, not possible when no more substrate is available or if the lactic acid bacteria have been inhibited by the high lactic acid concentration (Jay 1986).

Fermentation was more effective when the inoculum size was increased from $10^{7}$ to $10^{9} \mathrm{cfu} /$ $\mathrm{g}$ as shown by a lower final $\mathrm{pH}$ and increased lactic acid production. Owing to the great expense of increasing the inoculum size, preheating the offal might be a preferable alternative to improve fermentation with lower inoculum size. Studies by Hassan and Heath (1986), however, showed no advantage to initial fermentation when fish offal was preheated before fermentation. 


\section{AGRICULTURAL SCIENCE IN FINLAND}

\section{Lassén, T. M.: Evaluation of conditions for fermentation of fish offal}

The fermentation process might also be improved by pre-acidification with other organic acids as more favourable growth conditions would be created for the lactic acid bacteria. Propionic acid was successfully used by Skrede and Nes (1988) to lower the initial pH in slaughter offal before fermentation with lactic acid bacteria. However, in the present study adjusting the initial $\mathrm{pH}$ to 6.5 and 6.0 resulted in almost the same final $\mathrm{pH}$ values as in non pre-acidified samples. This finding supports the results of Urlings (1992), suggesting that pre-acidification is unnecessary for a successful fermentation.

Redox potential may be measured to estimate the growth conditions of anaerobic bacteria (Wolstrup 1972) and to determine the oxygen content of biological material (Harrison 1971). Aerobic bacteria such as Bacillus demand high (positive) redox values, whereas anaerobic bacteria such as Clostridium demand low (negative) redox values (Jay 1986). Redox potential is always positive in the muscle and negative in the viscera of freshly caught herring (Huss and Larsen 1979). The redox potential in warmblooded animals reaches a negative value shortly after the animals have been slaughtered and remains negative until aerobic deterioration (Barnes and Ingram 1955, Wirth and Leistner 1970).

The results reported here clearly show that within treatment and sample measurements were very reproducible. Appropriate fermentation led to a low and stable redox potential $(-550 \mathrm{mV})$ after two days' fermentation, whereas inappropriate fermentation led to an increasing redox potentia increased $\mathrm{pH}$ and decreased lactic acid concentration after two days' fermentation. Measurements of redox potential thus provide an efficient, fast and inexpensive means of estimating bacterial spoilage.

The feasibility of using lactic acid fermentation to preserve raw fish by-products was demonstrated with herring offal as a model. It was concluded that fermentation was most effective with an inoculum size of $10^{9} \mathrm{cfu} / \mathrm{g}$ L.p and $5 \%$ dextrose at $25^{\circ} \mathrm{C}$, as shown by sufficient initial lactic acid production, a rapid $\mathrm{pH}$ decrease and an eventual low and stable final pH. For economic reasons, however, an inoculum size of $10^{8}$ $\mathrm{cfu} / \mathrm{g}$ offal was considered more realistic for biopreservation of animal by-products. Measurement of redox potential was found to be a reliable and simple way of expressing conditions for bacterial growth under anaerobic fermentation and storage.

Acknowledgements. Financial support for this study was provided by the Academy of Finland. Sincere gratitude is due to Mrs Birthe Jessen of Chr. Hansen's Lab A/S, Denmark for providing the starter cultures used in the study, to Associate Professor Niels Enggaard Hansen for valuable suggestions and comments on the manuscript, and to Associate Professor Anne-Helene Tauson for her constructive criticism, and for her skilful help with the statistical analysis.

\section{References}

Baird-Parker, A. C. 1980. Organic Acids. In: Silliker, J. H. (ed.). Microbial Ecology of Foods. Vol. 1. Academic Press, London. p. 126-135.

Barnes, E. M. \& Ingram, M. 1955. Changes in the oxidation-reduction potential of the sterno-cephalicus muscle of the horse after death in relation to the development of bacteria. Journal of Science of Food and Agriculture 6: 448-455.

Beck, T. 1978. The microbiology of silage fermentation. In: McCullough, M. E. (ed.). Fermentation of Silage - A Review National Feed Ingredients Association, lowa. p. 61-115.
Harrison, D. E. F. 1971. Abstracts from Fift International Symposium and study Group on continuous culture of Microorganisms. Oxford. $39 \mathrm{p}$.

Hassan, T. L. \& Heath, J. L. 1986. Biological fermentation of fish waste for potential use in animal and poultry feeds. Agricultural Wastes 15: 1-15.

Hurst, A. 1973. Microbial antagonists in foods. Can. Inst. Food Sci. Technol. J. 6: 80-90.

- \& Collins-Thomsson, D. L. 1979. Food as a bacterial habit. In: Alexander, M. (ed.). Advances in Microbial Ecology. New York and London, Plenum Press. p. 79-134. Huss, H. H. \& Larsen, A. 1979. The post mortem chang- 


\title{
AGRICULTURAL SCIENCE IN FINLAND
}

Vol. 4: 11-17.

es in the oxidation-reduction potential of fish muscle and internal organs. In: Sobolenska-Ceronik, K. et al. (eds.). Food as an Ecological Environment for Pathogenic and Index Organism. Proceedings of the 10th International Symposium of IAMS (International Association of Microbial Societies), Ars, Poland. p. 265-279.

Ingram, M., Ottaway, F. J. H. \& Coppoch, J. B. M. 1959. The preservative action of acid substances in food. Chemistry Index. Part 2. p. 1154-1162.

Jay, J. M. 1986. Modern Food Microbiology. Third edition, Van Nostrand, C.O., New York. 622 p.

Lassén, T. M. 1995a. Lactic acid fermentation of fish offal and chicken by-product with different starter cultures. Agricultural Science in Finland 4: 19-26.

$-1995 \mathrm{~b}$. Biological quality of biofermented fish offal and chicken by-product. Agricultural Science in Finland 4: 2733.

Lindgren, S. E. \& Clevström, G. 1978. Antibacterial Activity of Lactic Acid Bacteria. 1: Activity of fish silage, a cerealstarter and isolated organisms. Swedish Journal of agricultural Research 8: 61-66.

- \& Pleje, M. 1983. Silage fermentation of fish and fish waste products with lactic acid bacteria. Journal of the Science of Food and Agriculture 34: 1057-1067.

Mackie, J. M., Hardey, R. \& Hobbs, G. (eds.) 1971. Fermented fish products. FAO Fisheries Reports, No. 100. $54 \mathrm{p}$.

Nester, E. W., Roberts, E. C., Pearsall, N. N. \& McCarthy, B. J. 1978. Microbiology. 2nd edition. Holt-Saunders International Editions, N.Y. USA. 747 p.

Nilsson, R. \& Rydin, C. 1965. A new method of ensiling foodstuffs and feedstuffs of vegetable and animal origin. Enzymologia 29: 126-142.
Pelczar, M. J., Reid, R. D. \& Chan, E. C. S. 1977. Microbiology. Mcgrave-Hill Inc. 952 p.

Raa, J. 1980. Biochemistry of microbial fish spoilage and preservation by lactic acid bacteria and added acid. In: Emejuavie, S. O. et al. (eds.). Global Impacts of Applied Microbiology, Sixth International Conference, Congress Proceedings Lagos, Nigeria. p. 3-17.

SAS 1985 SAS/STAT® User's Guide: Statistics, Version 5 Edition. SAS Institute Inc. Cary, NC. 956 p.

Skrede, A. \& Nes, I. F. 1988. Slaughterhouse by-products preserved by Lactobacillus plantarum fermentation as feed for mink and foxes. Animal Feed Science and Technology 20: 287-298.

Speck, M .L. 1981. Use of microbial cultures. Dairy Products. Food Technology 35: 71-73.

Stanton, W. R. \& Yeoh, Q. L. 1977. Low salt fermentation method for conserving trash fish waste under SE Asian conditions. Proceedings of the Conference on Handling, Processing and Marketing of Tropical Fish. TPI, London UK. p. 268-277.

Urlings, H. A. P. 1992. Fermentation of animal by-products. Microbiological aspects of processing, epidemiology and animal nutrition. Diss. Utrecht University, Faculty of Veterinary Medicine, Department of the Science of Food of Animal Origin, Utrecht, The Netherlands. 135 p. Wirth, F. \& Leistner, L. 1970. Redoxpotentiale in Fleischkonserven. Fleischwirtschaft 50: 491-492.

Wolstrup, J. 1972. Mikrobiologiske undersøgelser af vomindholdet fra køer fodret med sukkerroer, græsensilage, hø og græs. Thesis. Mikrobiologisk Laboratorium, Royal Veterinary and Agricultural University, Denmark. $47 \mathrm{p}$.

\section{SELOSTUS}

\section{Kalajätteen fermentaatio-olosuhteiden arvionti}

\author{
T. Mikael Lassén \\ Royal Veterinary and Agricultural University, Tanska
}

\begin{abstract}
Kalajätteen maitohappofermentaation olosuhteita tutkittiin erilaisilla kasvualustoilla ( 2,5 ja $10 \%$ dekstroosia), maitohapolla ennalta hapottamisella ( $\mathrm{pH}: n$ laskeminen 6,8:sta 6,5:een tai 6,0:aan) ja erikokoisilla Lactobacillus plantarum siirrostuksilla $\left(10^{7}, 10^{8} \mathrm{ja}\right.$ $\left.10^{9} \mathrm{cfu} / \mathrm{g}\right) . \mathrm{pH}: t a$ ja maitohappopitoisuutta seurattiin kahden viikon varastointijaksolla. Pienoismalli kalajätteen fermentaatiosiilosta rakennettiin ja selvitettiin redox-potentiaalin mittaamisen soveltuvuutta bakteerien kasvuolosuhteiden arvioimiseen.
\end{abstract}

Fermentaatiolle suotuisimmat olosuhteet (alhainen ja vakaa $\mathrm{pH}$ sekä korkea maitohappopitoisuus) saavutettiin $10^{8} \mathrm{cfu} / \mathrm{g}$ siirrostuksella ja $5 \%$ dekstroosipitoisuudella kasvualustassa. Ennalta hapottaminen maitohapolla ei vaikuttanut lopulliseen $\mathrm{pH}$ :een. Redox-potentiaalin osoitettiin antavan luotettavan arvion kasvuolosuhteista bakteereille, jotka elävät hapettomissa olosuhteissa. Tällöin redox-potentiaalisuus laski nopeasti alle $-550 \mathrm{mV}$ kalasäilörehussa, jonka maitohappopitoisuus oli korkea. 